\title{
HIERARKI AFIKSASI PADA VERBA BAHASA INDONESIA (BI) DARI PERSPEKTIF MORFOLOGI DERIVASI DAN INFLEKSI ${ }^{1)}$
}

\author{
Ermanto \\ Universitas Negeri Padang
}

\begin{abstract}
Abstrak
Penelitian ini mengkaji hierarki afiksasi pada verba BI dari perspektif morfologi derivasi dan infleksi. Jenis penelitian ini adalah penelitian kualitatif dengan metode penelitian linguistik struktural dan memanfaatkan tata bahasa kasus untuk kajian semantis. Temuan penelitian adalah pada verba afiksasi BI terdapat lima pola hierarki afiksasi. Pertama, pola (I) adalah D + PROSES INFLEKSI. Kedua, pola (II) adalah (D + PROSES DERIVASI) + PROSES INFLEKSI. Ketiga, pola (III) adalah ( $(D+$ PROSES DERIVASI $)+$ PROSES DERIVASI) + PROSES INFLEKSI. Keempat, pola (IV) adalah D + PROSES DERIVASI. Kelima, pola (V) adalah D + PROSES INFLEKSI (afiks infleksi ber-).
\end{abstract}

Kata-kata kunci: hierarki afiksasi, verba afiksasi, afiks derivasi, afiks infleksi

Abstract

This reasearch studies the hirarchy of affixation on Indonesian verb from derivational and inflectional morphology perspectives. It is a qualitative reseach applying structural linguistic method and making use of case grammar for semantic analysis. The result indicates that Indonesian affixed verb has five affixation hirarchical patterns including (1) D+ Inflection process; (2) D + derivation process + inflection process; (3) $D+$ derivaion process + derivation process + inflection proces; (4) $D+$ derivation process; and ( $D+$ inflection process (inflectinal affix ber-)

\section{Pendahuluan}

Pengkajian derivasi dan infleksi dalam bahasa Indonesia belum banyak dilakukan oleh pakar linguistik. Kridalaksana (1996:11) menyatakan bahwa perbedaan antara derivasi dan infleksi dalam BI tidak begitu jelas, sampai ada penelitian yang memuaskan. Samsuri (1987:199) menyarankan perlunya kajian

${ }^{1)}$ Topik ini adalah bagian dari penelitian untuk disertasi penulis di UNS dengan judul "Derivasi dan Infleksi Verba Bahasa Indonesia”

Vol. 14, No. 26, Maret 2007

SK Akreditasi Nomor: 39/Dikti/Kep. 2004 
morfologi derivasi dan infleksi dalam bahasa Indonesia sehingga diketahui apakah pengertian derivasi dan infleksi bisa diterapkan secara konsisten di dalam bahasa Indonesia. Alieva, dkk. (1991) selain mengakui adanya proses derivasi dalam morfologi BI, juga mengakui adanya beberapa paradigma infleksi dalam morfologi bahasa Indonesia walaupun dengan jumlah afiks infleksi yang relatif sedikit dibandingkan dengan jumlah afiks derivasi. Jumlah afiks infleksi yang terbatas seperti dikemukakan Alieva, dkk. tersebut, sesuai dengan pendapat Nida (1999:99) bahwa afiks infleksi, secara statistik, cenderung kurang beragam (relatif sedikit) sedangkan afiks derivasi, secara statistik, cenderung lebih beragam (relatif banyak). Chaer (2003) juga telah menyinggung morfologi derivasi dan infleksi pada beberapa afiks dalam bahasa Indonesia. Hal tersebut menjadi alasan perlunya penelitian morfologi derivasi dan infleksi dalam bahasa Indonesia, khususnya verba turunan BI.

Buku-buku tata bahasa Indonesia tidak banyak mengkaji proses morfologi derivasi dan infleksi. Hal itu mungkin disebabkan oleh pengkajian morfologi BI tidak menggunakan perspektif morfologi derivasi dan morfologi infleksi. Kridalaksana (1996) telah membicarakan jenis afiks pembentuk verba, ajektiva, nomina, adverbia, numeralia, dan interogativa di dalam bab tiga (halaman 28-87). Namun, Kridalaksana tidak mengidentifikasi afiks derivasi dan afiks infleksi. Hal itu disebabkan oleh Kridalaksana memang tidak mengkaji proses pembentukan kata itu dari perspektif morfologi derivasi dan infleksi.

Alwi, dkk. (1998, edisi ketiga) telah membicarakan afiksasi dan reduplikasi pada verba (halaman 117-150), afiksasi dan reduplikasi pada adjektiva (halaman 
188-166), afiksasi dan reduplikasi pada nomina (halaman 223-240). Namun, Alwi, dkk tidak mengidentifikasi afiks yang bersifat derivasi dan atau yang bersifat infleksi. Hal itu disebabkan oleh proses afiksasi memang tidak dikaji dari perspektif morfologi derivasi dan infleksi. Selain itu, Chaer (2003) dalam bukunya berjudul Seputar Tata Bahasa Baku Bahasa Indonesia menyatakan bahwa buku Tata Bahasa Baku Bahasa Indonesia masih memiliki kekurangan. Namun, Alwi, dkk. (1998:vi) menyatakan bahwa "kajian serta penelitian yang mendalam mengenai berbagai aspek (baca: hal) bahasa Indonesia akan merupakan bahan yang akan dimanfaatkan dalam edisi berikutnya”. Pernyataan Alwi, dkk tersebut mengimplikasikan bahwa kajian bahasa Indonesia akan dimanfaatkan untuk penyempurnaan buku Tata Bahasa Baku Bahasa Indonesia.

Bertolak dari uraian di atas, pengkajian morfologi BI patut dilakukan dari teori morfologi derivasi dan infleksi. Ihwal pembagian morfologi atas ranah derivasi dan infleksi, setidaknya dapat ditelusuri kembali berdasarkan pandangan Lyons (1968), Matthews (1974), dan Bauer (1983). Seperti halnya pembagian derivasi dan infleksi yang dinyatakan Lyons (1968), Matthews (1974:38) juga membagi ranah morfologi atas dua subbidang utama, yakni (1) proses infleksional dan (2) proses word formation yang dipisahkan lagi atas: (a) proses derivasi dan (b) proses komposisi (pemajemukan). Matthews (1974:41) menyimpulkan bahwa morfologi terdiri atas dua subbidang, yakni (1) morfologi infleksi dan (2) morfologi leksikal (morfologi derivasional). Bauer (1988:73) juga menyatakan bahwa morfologi secara tradisional dibagi atas dua cabang yakni derivasi dan infleksi; dasar pembedanya 
adalah derivasi menghasilkan leksem baru dan infleksi menghasilkan bentuk-bentuk kata (kata gramatikal) dari leksem. Pembagian dua ranah morfologi seperti dilakukan oleh Matthews (1974) dan Bauer (1988) tersebut juga dilakukan oleh Widdowson (1997). Menurut Widdowson (1997:46-47) morfologi berkonsentrasi pada dua fenomena yang berbeda, yakni derivasi dan infleksi. Oeh karena itu, dalam perkembangan ilmu morfologi hingga saat ini, para pakar linguistik lazim membicarakan morfologi dari ranah derivasi dan infleksi. Pakar linguistik yang juga membagi morfologi atas derivasi dan infleksi adalah seperti Scalise (1984:103-114), Dik dan Koij (1994:170-171), Stump (2001:14-18), Beard (2001:44-45), Aronof and Fudeman (2005:160), dan Boiij (2005:112-115)

Afiksasi yang terjadi pada verba BI dapat dijelaskan dari perspektif morfologi derivasi dan infleksi. Proses derivasi dan infleksi yang terdapat dalam verba turunan seperti memecahkan dalam kalimat (Andi) memecahkan (kaca jendela tersebut) terjadi secara hierarkis. Hierarki pembentukan verba turunan pada umumnya akan mengikuti kaidah tertentu, yakni proses derivasi terjadi lebih dahulu dan kemudian dapat diikuti proses infleksi (Robins, 1992:301; Bauer, 1988:83; Scalise, 1984:103; Hatch and Brown 1995:266; Yule, 1996:78; Radford, dkk, 1999:166). Istilah proses derivasi dan proses infleksi ini didasarkan pada istilah yang digunakan Matthews (1974:37-38). Selain itu, dapat pula dipahami bahwa paradigma infleksi aktif-pasif akan terjadi pada verba AKSI-PROSES (verba transitif). Pada pembentukan verba AKSI-PROSES (verba transitif) dari D verba KEADAAN, verba PROSES, verba 
AKSI, proses derivasi (dengan afiks derivasi) terjadi lebih dahulu, kemudian diikuti oleh proses infleksi (dengan afiks infleksi) seperti paradigma infleksi aktif-pasif.

Dalam proses pembentukan verba turunan BI seperti memecahkan, afiks kan lebih dahulu mengimbuh pada D pecah (verba PROSES/ verba intransitif) menjadi -pecahkan (verba AKSI-PROSES/ verba transitif). Penulisan bentuk -pecahkan yang memakai tanda (-) di awal verba menunjukkan bahwa verba itu adalah verba AKSI-PROSES (lihat Alieva, 1991:107) yang selalu bisa diimbuh oleh afiks infleksi seperti meN- dan di-. Proses morfologi (istilah ini sudah digunakan oleh beberapa pakar seperti Poedjosoedarmo, dkk., 1979; Ramlan, 1987; Kridalaksana, 1996) dari leksem PECAH menjadi leksem PECAHKAN adalah proses derivasi, kemudian diikuti oleh proses infleksi yakni mengubah leksem PECAHKAN (verba AKSI-PROSES) menjadi kata gramatikal (bentuk kata) memecahkan (verba AKSIPROSES). Jika bentuk memecahkan disusun dalam paradigma infleksi dalam bahasa Indonesia seperti dinyatakan sebelumnya, maka bentuk-bentuknya adalah memecahkan, dipecahkan, kaupecahkan, kupecahkan. Jadi, leksem PECAH seperti dalam (kaca jendela itu) pecah berbeda dengan leksem PECAHKAN seperti dalam (Andi) memecahkan (kaca jendela itu) karena adanya perbedaan fitur-fitur semantis.

Selain itu, afiksasi pada verba turunan seperti memperbesar, membesarkan dapat ditentukan hierarki dan fungsinya dengan morfologi derivasi dan infleksi. Jika kita berpijak pada kaidah yang menyatakan bahwa proses infleksi terjadi setelah proses derivasi, maka afiks meN- pada kedua bentuk itu tidaklah berfungsi untuk menjadikan verba transitif (bukan proses derivasi). Hal ini dapat disusun dalam 
paradigma infleksi yang digunakan sebelumnya yakni memperbesar, diperbesar, kauperbesar, kuperbesar, dan bentuk membesarkan, dibesarkan, kaubesarkan, kubesarkan. Dengan demikian, jelas bahwa afiks meN- hanya berfungsi sebagai pemarkah aktif dalam paradigma infleksi yakni, bahwa S adalah AGEN. Selanjutnya, afiks pembentuk verba AKSI-PROSES (verba transitif) pada verba memperbesar dan membesarkan adalah afiks per- pada verba memperbesar dan afiks -kan pada verba membesarkan.

Hierarki pembentukan verba memperbesar adalah proses derivasi dari D besar (A) menjadi -perbesar (verba AKSI-PROSES/verba transitif), kemudian diikuti proses infleksi dengan afiks infleksi meN- --yakni pemarkah aktif atau pemarkah bahwa S adalah AGEN-- menjadi memperbesar. Demikian juga hierarki pembentukan verba membesarkan adalah proses derivasi dari D besar (A) menjadi besarkan (verba AKSI-PROSES/ verba transitif), kemudian diikuti proses infleksi dengan afiks infleksi meN- --yakni pemarkah aktif atau pemarkah bahwa S adalah AGEN-- menjadi membesarkan. Hal ini jelas berbeda dengan Alwi, dkk. dalam TBBBI (1998:128) yang menyatakan bahwa afiks memper- dan meN—kan pada verba memperbesar, membesarkan berfungsi membentuk verba transitif dari adjektiva.

Pada verba afiksasi yang memiliki beberapa afiks, afiks-afiks tersebut mengimbuh secara hierarkis. Jika pada verba afiksasi terdapat afiks derivasi dan afiks infleksi, maka pengimbuhan itu terjadi menurut kaidah tertentu (kaidah umum). Kaidah umum tersebut adalah proses derivasional akan terjadi lebih dahulu dan 
kemudian diikuti oleh proses infleksi. Kaidah ini dinyatakan oleh banyak pakar bahasa seperti Robins (1992:301), Bauer (1988:83), Scalise (1984:103), Hatch and Brown (1995:266), Yule (1996:78), Radford, dkk. (1999:168). Hierarki pengimbuhan afiks-afiks pada verba akan membentuk lapisan-lapisan penurunan kata. Menurut Bloomfield (1995:215) tataran-tataran struktur morfologis pada kata yang berstruktur kompleks dapat dibagi menjadi dua lapisan: (1) lapisan luar yakni konstruksi inflektif dan (2) lapisan dalam yakni pembentukan kata (konstruksi derivatif). Dari teori kesemestaan bahasa, Greenberg (dalam Sudaryanto, 1989:147) mengemukakan bahwa bila baik derivasi maupun infleksi kedua-duanya mengikuti akar atau kedua-duanya mendahului akar, maka derivasi itu selalu di antara akar dan infleksi.

Berdasarkan uraian di atas, tulisan ini bertujuan untuk mengkaji hierarki afiksasi yang terjadi pada verba afiksasi yang diturunkan dari dasar nomina, adjektiva, dan verba. Artinya, dalam tulisan ini akan diungkapkan pola-pola hierarki afiksasi pada verba BI.

\section{Metode Penelitian}

Jenis penelitian ini adalah penelitian kualitatif dengan metode penelitian linguistik struktural dan memanfaatkan teori tata bahasa kasus Chafe (1970) dan Fillmore (1971) untuk hal semantis verba. Objek penelitian ini adalah verba afiksasi BI yang diturunkan dari nomina (DN), adjektiva (DA) dan verba (DV). Data penelitian adalah kalimat (tuturan) yang di dalamnya terdapat verba afiksasi BI yang mengisi fungsi predikat kalimat. Sumber data adalah sumber tulis yakni, tajuk 
rencana, berita dan artikel pada surat kabar Kompas, majalah Tempo, majalah Intisari, jurnal Linguistik Indonesia (terbitan 2005-2006), dan dipilih beberapa buku terbitan Gramedia (terbitan tahun 2000-2005). Sumber tulis lainnya yang digunakan adalah Kamus Besar Bahasa Indonesia (KBBI) edisi ketiga tahun 2005. Selain sumber tulis, digunakan pula sumber lisan yakni peneliti sendiri sebagai sumber data penelitian ini (Sudaryanto, 1993:161).

Metode analisis yang digunakan adalah metode padan intralingual seperti yang dikemukakan Mahsun (2005:112). Istilah metode padan intralingual ini adalah sama dengan metode agih yang dikemukakan oleh Sudaryanto (1993:15). Menurut Mahsun (2005:112) metode padan intralingual adalah metode analisis dengan cara menghubungbandingkan unsur-unsur yang bersifat lingual. Penjelasan Mahsun ini relatif sama dengan penjelasan Sudaryanto (1993:15) dengan metode agih, yakni metode analisis yang alat penentunya justru bagian dari bahasa itu sendiri. Untuk penentuan hierarki afiksasi pada verba BI (tujuan penelitian ketiga) digunakan dua teknik analisis yakni teknik oposisi dua-dua (Subroto, 1992:72) dan teknik lesap (Sudaryanto, 1993:41).

\section{Hasil Penelitian dan Pembahasan}

Hierarki afiksasi pada verba BI dianalisis menggunakan teknik oposisi duadua antara turunan (verba afiksasi) dengan D. Berdasarkan analisis, pola hierarki afiksasi dibedakan pada: (1) V AKSI PROSES (V Transitif) dan (2) V KEADAAN, V PROSES, V AKSI (V Intransitif). 


\subsection{Hierarki Afiksasi pada V AKSI PROSES (V TRANSITIF)}

Hierarki afiksasi pada V AKSI PROSES ( Transitif) ditemukan tiga hal berikut ini. Pertama, jika verba AKSI PROSES (V Transitif) hanya memiliki satu afiks infleksi meN- atau afiks infleksi di-, maka hierarki afiksasi yang terjadi hanya satu kali proses infleksi. Pola (I) dengan hierarki afiksasi adalah D + PROSES INFLEKSI. Kedua, jika verba AKSI PROSES (V Transitif) selain memiliki afiks infleksi meN- atau afiks infleksi $d i$ - juga memiliki afiks derivasi lain seperti -kan, i, per-/-kan, per-/-i, per- maka hierarki afiksasi adalah dua kali (proses derivasi diikuti proses infleksi). Pola (II) hierarki afiksasi adalah (D + PROSES DERIVASI) + PROSES INFLEKSI. Ketiga, jika verba AKSI PROSES (V Transitif) selain memiliki afiks infleksi meN- atau afiks infleksi $d i$ - juga memiliki afiks derivasi lain seperti afiks ber-, dan -kan maka hierarki afiksasi adalah tiga kali (proses derivasi, diikuti proses derivasi dan diakhiri proses infleksi). Ketiga proses itu adalah pengimbuhan afiks derivasi ber- pada D, dilanjutkan afiks derivasi - kan dan afiks infleksi meN- atau di-. Pola (III) hierarki afiksasi adalah ((D + PROSES DERIVASI) + PROSES DERIVASI) + PROSES INFLEKSI. Hal itu dijelaskan berikut ini.

Verba AKSI PROSES (V Transitif) yang hanya memiliki afiks meN- atau dimaka jelas hierarki afiksasi yang terjadi adalah $D+$ PROSES INFLEKSI. Artinya, D yang diimbuh adalah V AKSI PROSES (V Transitif) yang berbentuk simpel (monomorfem) dan secara otomatis selalu diimbuh oleh afiks infleksi meN- atau afiks infleksi di-. Proses infleksi ini membentuk kata gramatikal dengan kategori V 
AKTIF atau V PASIF. Kata gramatikal ini tidak dapat diimbuh lagi oleh afiks derivasi atau afiks infleksi lain. Kata gramatikal tersebut sudah bersifat tertutup. Nida (1949:99) menyebutkan bahwa hasil bentukan proses infleksi ini tidak dapat menjadi dasar untuk proses morfologi berikutnya. Hal ini bersesuaian dengan Scalise (1984:114) yang menyatakan bahwa bentukan kaidah infleksi tidak dapat diterapkan kembali sebagai dasar untuk proses morfologi. Kata gramatikal tersebut sudah bersifat tertutup untuk proses selanjutnya Bauer (1988: 83-84).

Hierarki afiksasi pada V AKSI PROSES (V Transitif) dengan POLA (I): $D+$ PROSES INFLEKSI (1) dapat dijelaskan berikut ini.

POLA (I): D + PROSES INFLEKSI.

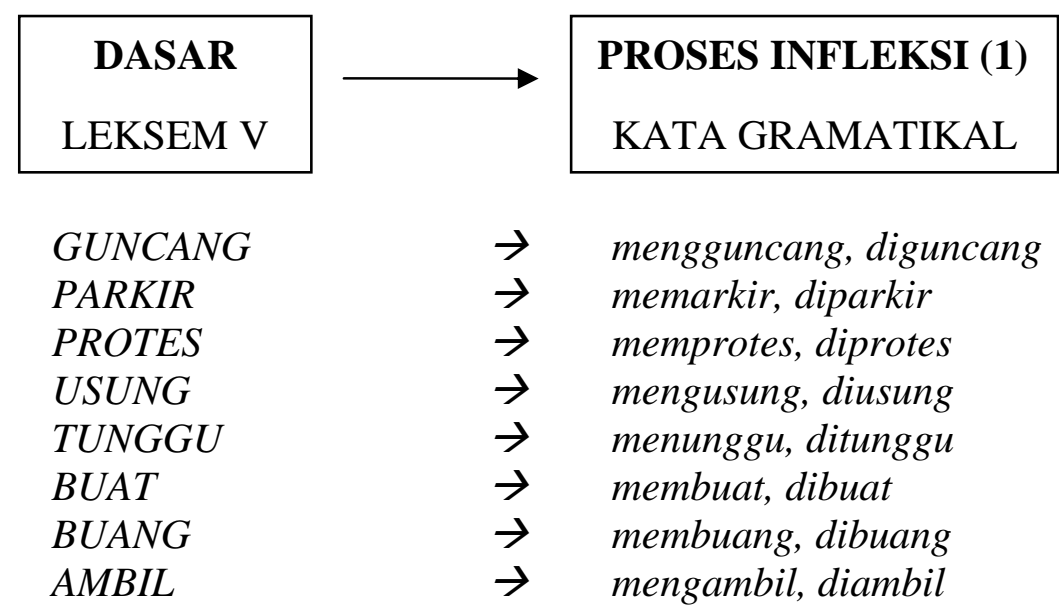

Hierarki afiksasi pada verba di atas adalah pengimbuhan afiks infleksi meNdan di- pada leksem V dengan proses infleksi. Pengimbuhan afiks infleksi (Proses Infleksi 1) membentuk kata gramatikal berkategori AKTIF dan PASIF dari leksem V. Kata gramatikal berafiks meN- adalah V AKTIF, dan kata gramatikal berafiks diadalah V PASIF. Pada DV AKSI PROSES yang berbentuk simpel (monomorfem) secara otomatis akan mengalami proses infleksi dengan afiks infleksi meN- dan di-. 
Jika verba AKSI PROSES (V Transitif) selain memiliki afiks infleksi meNatau di- juga memiliki afiks -kan, -i, per-/-kan, per-/-i, per-, maka hierarki afiksasi adalah pengimbuhan afiks derivasi -kan, -i, per-/-kan, per-/-i, per- (proses derivasi) dan diikuti afiks infleksi meN- atau di- (proses infleksi). Pola hierarki afiksasi adalah D + PROSES DERIVASI (1) + PROSES INFLEKSI (2). Pada proses derivasi (1), afiks derivasi mengimbuh pada DN, DA, DV KEADAAN, DV PROSES, DV AKSI untuk menurunkan V AKSI PROSES (V Transitif) atau mengimbuh pada DV AKSI PROSES untuk menurunkan V AKSI PROSES dengan fitur semantis tertentu. Pada proses infleksi (2), afiks infleksi mengimbuh pada V AKSI PROSES untuk membentuk kata gramatikal kategori AKTIF atau PASIF. Kata gramatikal yang telah diturunkan dengan proses infleksi ini tidak dapat diimbuh lagi oleh afiks derivasi atau afiks infleksi lain (lihat Nida, 1949:99; Scalise, 1984:114; Bauer, 1988: 83-84).

Hierarki afiksasi pada V AKSI PROSES (V Transitif) yang diturunkan dari DN dengan POLA (II): D + PROSES DERIVASI (1) + PROSES INFLEKSI (2) dapat dijelaskan berikut ini.

POLA (II): D + PROSES DERIVASI (1) + PROSES INFLEKSI (2).

\begin{tabular}{|c|c|c|}
\hline DASAR \\
LEKSEM N
\end{tabular}$\rightarrow \begin{gathered}\text { PROSES DERIVASI (1) } \\
\text { LEKSEM V }\end{gathered} \rightarrow \begin{gathered}\text { PROSES INFLEKSI (2) } \\
\text { KATA GRAMATIKAL }\end{gathered}$

$\begin{array}{lllll}\text { CONTOH } & \rightarrow & \text { CONTOHKAN } \rightarrow & \text { mencontohkan,dicontohkan } \\ \text { JANJI } & \rightarrow & \text { JANJIKAN } & \rightarrow & \text { menjanjikan, dijanjikan } \\ \text { HARGA } & \rightarrow & \text { HARGAI } & \rightarrow & \text { menghargai, dihargai } \\ \text { SALAM } & \rightarrow & \text { SALAMI } & \rightarrow & \text { menyalami, disalami } \\ \text { BUDAK } & \rightarrow & \text { PERBUDAK } & \rightarrow & \text { memperbudak, diperbudak } \\ \text { ALAT } & \rightarrow & \text { PERALAT } & \rightarrow & \text { memperalat, diperalat }\end{array}$




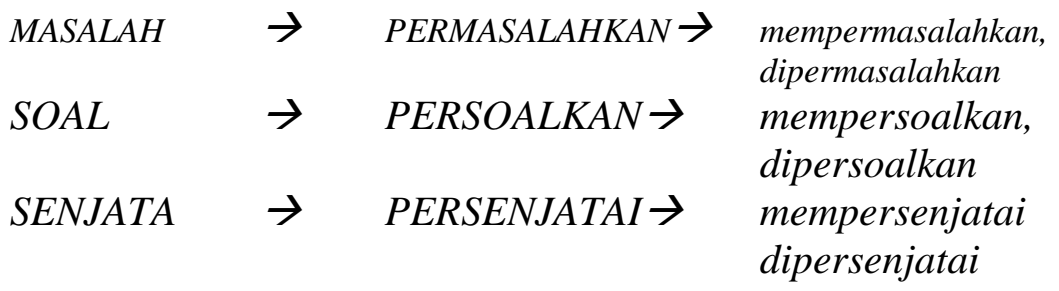

Pada contoh verba di atas, terlihat adanya dua hierarki pengimbuhan afiks. Hieraraki yang pertama adalah pengimbuhan afiks derivasi -kan, -i, per-, per-/-kan, per-/-i pada DN dengan proses derivasi transposisional dan hierarki yang kedua adalah pengimbuhan afiks infleksi meN- dan di- dengan proses infleksi. Pengimbuhan afiks derivasi (Proses Derivasi 1) menurunkan leksem V dari DN dan pengimbuhan afiks infleksi (Proses Infleksi 2) membentuk kata gramatikal berkategori AKTIF dan PASIF dari leksem V.

Selain itu, hierarki afiksasi pada verba AKSI PROSES yang diturunkan dari DN dengan proses konversi sesuai dengan POLA (II): D + PROSES DERIVASI (1) + PROSES INFLEKSI (2) dapat dijelaskan berikut ini.

POLA (II): D + PROSES DERIVASI (1) + PROSES INFLEKSI (2).

\begin{tabular}{|c|c|c|}
\hline DASAR \\
\end{tabular}$\rightarrow \begin{gathered}\begin{array}{c}\text { PROSES DERIVASI (1) } \\
\text { PROSES KONVERSI } \\
\text { LEKSEM V }\end{array} \\
\end{gathered} \rightarrow \begin{gathered}\text { PROSES INFLEKSI (2) } \\
\text { KATA GRAMATIKAL }\end{gathered}$

$\begin{array}{lllll}\text { DESAIN } & \rightarrow & \text { DESAIN } & \rightarrow & \text { mendesain, didesain } \\ \text { DONGKRAK } & \rightarrow & \text { DONGKRAK } & \rightarrow & \text { mendongkrak, didongkrak } \\ \text { KAPUR } & \rightarrow & \text { KAPUR } & \rightarrow & \text { mengapur, dikapur } \\ \text { TELEPON } & \rightarrow & \text { TELEPON } & \rightarrow & \text { menelepon, ditelepon } \\ \text { HUKUM } & \rightarrow & \text { HUKUM } & \rightarrow & \text { menghukum, dihukum } \\ \text { MONITOR } & \rightarrow & \text { MONITOR } & \rightarrow & \text { memonitor, dimonitor } \\ \text { GERGAJI } & \rightarrow & \text { GERGAJI } & \rightarrow & \text { menggergaji, digergaji } \\ \text { GERINDA } & \rightarrow & \text { GERINDA } & \rightarrow & \text { menggerinda, digerinda } \\ \text { GUNTING } & \rightarrow & \text { GUNTING } & \rightarrow & \text { menggunting, digunting }\end{array}$


Pada contoh verba di atas, terlihat adanya dua hierarki pengimbuhan afiks. Hierarki yang pertama adalah pengimbuhan afiks derivasi zero pada DN dengan proses derivasi zero (proses konversi) dan hierarki yang kedua adalah pengimbuhan afiks infleksi $m e N$ - dan di- dengan proses infleksi. Proses derivasi zero atau proses konversi (Proses Derivasi 1) menurunkan leksem V dari DN dan pengimbuhan afiks infleksi (Proses Infleksi 2) membentuk kata gramatikal berkategori AKTIF dan PASIF dari leksem V.

Hierarki afiksasi pada verba AKSI PROSES yang diturunkan dari DA dengan POLA (II): D + PROSES DERIVASI (1) + PROSES INFLEKSI (2) dijelaskan berikut ini.

POLA (II): D + PROSES DERIVASI (1) + PROSES INFLEKSI (2).

\begin{tabular}{|c|c|c|}
\hline DASAR \\
LEKSEM A
\end{tabular}$\rightarrow \begin{gathered}\text { PROSES DERIVASI (1) } \\
\text { LEKSEM V }\end{gathered} \rightarrow \begin{gathered}\text { PROSES INFLEKSI (2) } \\
\text { KATA GRAMATIKAL }\end{gathered}$

$\begin{array}{lllll}\text { PADAT } & \rightarrow & \text { PADATI } & \rightarrow & \text { memadati, dipadati } \\ \text { SAKIT } & \rightarrow & \text { SAKITI } & \rightarrow & \text { menyakiti, disakiti } \\ \text { CEPAT } & \rightarrow & \text { PERCEPAT } & \rightarrow & \text { mempercepat, dipercepat } \\ \text { LUAS } & \rightarrow & \text { PERLUAS } & \rightarrow & \text { memperluas, diperluas } \\ \text { LANCAR } & \rightarrow & \text { PERLANCAR } & \rightarrow & \text { memperlancar, diperlancar } \\ \text { KAYA } & \rightarrow & \text { PERKAYA } & \rightarrow & \text { memperkaya, diperkaya } \\ \text { BAIK } & \rightarrow & \text { PERBAIKI } & \rightarrow & \text { memperbaiki, diperbaiki } \\ \text { BARU } & \rightarrow & \text { PERBARUI } & \rightarrow & \text { memperbarui, diperbarui }\end{array}$

Pada contoh verba di atas, terlihat adanya dua hierarki pengimbuhan afiks. Hieraraki yang pertama adalah pengimbuhan afiks derivasi $-k a n,-i$, per-, per-/-i pada DA dengan proses derivasi transposisional dan hierarki yang kedua adalah pengimbuhan afiks infleksi $m e N$ - dan di- dengan proses infleksi. Pengimbuhan afiks 
derivasi (Proses Derivasi 1) menurunkan leksem V dari DA dan pengimbuhan afiks infleksi (Proses Infleksi 2) membentuk kata gramatikal berkategori AKTIF dan PASIF dari leksem V.

Selain itu, verba AKSI PROSES yang diturunkan dari DV KEADAAN, DV PROSES, DV AKSI sesuai dengan POLA (II): D + PROSES DERIVASI (1) + PROSES INFLEKSI (2) dijelaskan berikut ini.

POLA (II): D + PROSES DERIVASI (1) + PROSES INFLEKSI (2).

\begin{tabular}{|c|c|c|}
\hline DASAR \\
LEKSEM V
\end{tabular}$\rightarrow \begin{gathered}\text { PROSES DERIVASI (1) } \\
\text { LEKSEM V }\end{gathered} \rightarrow \begin{gathered}\text { PROSES INFLEKSI (2) } \\
\text { KATA GRAMATIKAL }\end{gathered}$

$\begin{array}{lllll}\text { ADA } & \rightarrow & \text { ADAKAN } & \rightarrow & \text { mengadakan, diadakan } \\ \text { SIAP } & \rightarrow & \text { SIAPKAN } & \rightarrow & \text { menyiapkan, disiapkan } \\ \text { CEMAS } & \rightarrow & \text { CEMASKAN } \rightarrow & \text { mencemaskan, dicemaskan } \\ \text { HILANG } & \rightarrow & \text { HILANGKAN } \rightarrow & \text { menghilangkan, dihilangkan } \\ \text { RUGI } & \rightarrow & \text { RUGIKAN } \rightarrow & \text { merugikan, dirugikan } \\ \text { UNTUNG } & \rightarrow & \text { UNTUNGKAN } \rightarrow & \text { menguntungkan, diuntungkan } \\ \text { MANDI } & \rightarrow & \text { MANDIKAN } & \rightarrow & \text { memandikan, dimandikan } \\ \text { LARI } & \rightarrow & \text { LARIKAN } & \rightarrow & \text { melarikan, dilarikan } \\ \text { PERCAYA } & \rightarrow & \text { PERCAYAI } & \rightarrow & \text { mempercayai, dipercayai } \\ \text { MARAH } & \rightarrow & \text { MARAHI } & \rightarrow & \text { memarahi, dimarahi } \\ \text { CURIGA } & \rightarrow & \text { CURIGAI } & \rightarrow & \text { mencurigai, dicurigai } \\ \text { CINTA } & \rightarrow & \text { CINTAI } & \rightarrow & \text { mencintai, dicintai } \\ \text { DUDUK } & \rightarrow & \text { DUDUKI } & \rightarrow & \text { menduduki, diduduki } \\ \text { DATANG } & \rightarrow & \text { DATANGI } & \rightarrow & \text { mendatangi, didatangi }\end{array}$

Pada contoh verba di atas, terlihat adanya dua hierarki pengimbuhan afiks. Hierarki yang pertama adalah pengimbuhan afiks derivasi $-k a n,-i$ pada DV KEADAAN, DV PROSES, DV AKSI (V Intransitif) dengan proses derivasi taktransposisional dan hierarki yang kedua adalah pengimbuhan afiks infleksi meNdan di- dengan proses infleksi. Pengimbuhan afiks derivasi (Proses Derivasi 1) 
menurunkan leksem V AKSI PROSES (V Transitif) dan pengimbuhan afiks infleksi (Proses Infleksi 2) membentuk kata gramatikal berkategori AKTIF dan PASIF.

Hierarki afiksasi pada verba AKSI PROSES dengan fitur semantis DIREKTIF, BENEFEKTIF, FREKUENTATIF, DURATIF-INTENSIF dengan POLA (II): D + PROSES DERIVASI (1) + PROSES INFLEKSI (2) dijelaskan berikut ini.

POLA (II): D + PROSES DERIVASI (1) + PROSES INFLEKSI (2).

\begin{tabular}{|c|c|c|}
\hline DASAR \\
LEKSEM V
\end{tabular}$\rightarrow \begin{gathered}\text { PROSES DERIVASI (1) } \\
\text { LEKSEM V }\end{gathered} \rightarrow \begin{gathered}\text { PROSES INFLEKSI (2) } \\
\text { KATA GRAMATIKAL }\end{gathered}$

$\begin{array}{lllll}\text { SUMBANG } & \rightarrow & \text { SUMBANGKAN } \rightarrow & \text { menyumbangkan, disumbangkan } \\ \text { SIRAM } & \rightarrow & \text { SIRAMKAN } \rightarrow & \text { menyiramkan, disiramkan } \\ \text { BERITAHU } & \rightarrow & \text { BERITAHUKAN } \rightarrow & \text { memberitahukan, diberitahukan } \\ \text { BAGI } & \rightarrow & \text { BAGIKAN } \rightarrow & \text { membagikan, dibagikan } \\ \text { TULIS } & \rightarrow & \text { TULISKAN } \rightarrow & \text { menuliskan, dituliskan } \\ \text { PILIH } & \rightarrow & \text { PILIHKAN } \rightarrow & \text { memilihkan, dipilihkan } \\ \text { BELI } & \rightarrow & \text { BELIKAN } \rightarrow & \text { membelikan, dibelikan } \\ \text { CARI } & \rightarrow & \text { CARIKAN } \rightarrow & \text { mencarikan, dicarikan } \\ \text { LEMPAR } & \rightarrow & \text { LEMPARI } \rightarrow & \text { melempari, dilempari } \\ \text { JUAL } & \rightarrow & \text { JUALI } & \rightarrow & \text { menjuali, dijuali } \\ \text { CAMPUR } & \rightarrow & \text { CAMPURI } \rightarrow & \text { mencampuri, dicampuri } \\ \text { TANGKAP } & \rightarrow & \text { TANGKAPI } \rightarrow & \text { menangkapi, ditangkapi } \\ \text { PUKUL } & \rightarrow & \text { PUKULI } \rightarrow \rightarrow & \text { memukuli, dipukuli } \\ \text { POTONG } & \rightarrow & \text { POTONGI } \rightarrow & \text { memotongi, dipotongi } \\ \text { HITUNG } & \rightarrow & \text { PERHITUNGKAN } \rightarrow & \text { memperhitungkan, diperhitungkan } \\ \text { TIMBANG } & \rightarrow & \text { PERTIMBANGKAN } \rightarrow & \text { mempertimbangkan, dipertimbangkan } \\ \text { LIHAT } & \rightarrow & \text { PERLIHATKAN } \rightarrow & \text { memperlihatkan, diperlihatkan } \\ \text { TONTON } & \rightarrow & \text { PERTONTONKAN } \rightarrow & \text { mempertontonkan, dipertontonkan } \\ \text { AJAR } & \rightarrow & \text { PELAJARI } \rightarrow & \text { mempelajari, dipelajari }\end{array}$

Pada contoh verba di atas, terlihat adanya dua hierarki pengimbuhan afiks. Hierarki yang pertama adalah pengimbuhan afiks derivasi -kan, -i, per/-kan, per-/-i pada DV AKSI PROSES (V Intransitif) dengan proses derivasi taktransposisional 
dan hierarki yang kedua adalah pengimbuhan afiks infleksi meN- dan $d i$ - dengan proses infleksi. Pengimbuhan afiks derivasi (Proses Derivasi 1) menurunkan leksem V AKSI PROSES (V Transitif) dengan fitur semantis DIREKTIF, BENEFEKTIF, FREKUENTATIF, DURATIF-INTENSIF dan pengimbuhan afiks infleksi (Proses Infleksi 2) membentuk kata gramatikal berkategori AKTIF dan PASIF.

Hierarki afiksasi dengan pola III terdapat pada sejumlah kecil verba afiksasi dalam BI seperti membelajarkan, dibelajarkan, memberangkatkan, diberangkatkan, memberlakukan, diberlakukan, memberhentikan, diberhentikan, memberdayakan, diberdayakan. Pada verba AKSI PROSES (V Transitif) seperti ini, hierarki afiksasi yang terjadi adalah tiga kali yakni (1) pengimbuhan afiks derivasi beR-, (2) pengimbuhan afiks derivasi -kan, dan (3) diikuti dengan pengimbuhan afiks infleksi meN- atau di-. Pola hierarki afiksasi yang terjadi adalah D + PROSES DERIVASI (1) + PROSES DERIVASI (2) + PROSES INFLEKSI (3). Hierarki afiksasi pada verba AKSI PROSES yang diturunkan dari DV AKSI PROSES, atau DN dengan POLA (III): D + PROSES DERIVASI (1) + PROSES DERIVASI (3)+ PROSES INFLEKSI (3) dijelaskan berikut ini.

POLA (III): D + PROSES DERIVASI (1) + PROSES DERIVASI (2) + PROSES INFLEKSI (3).

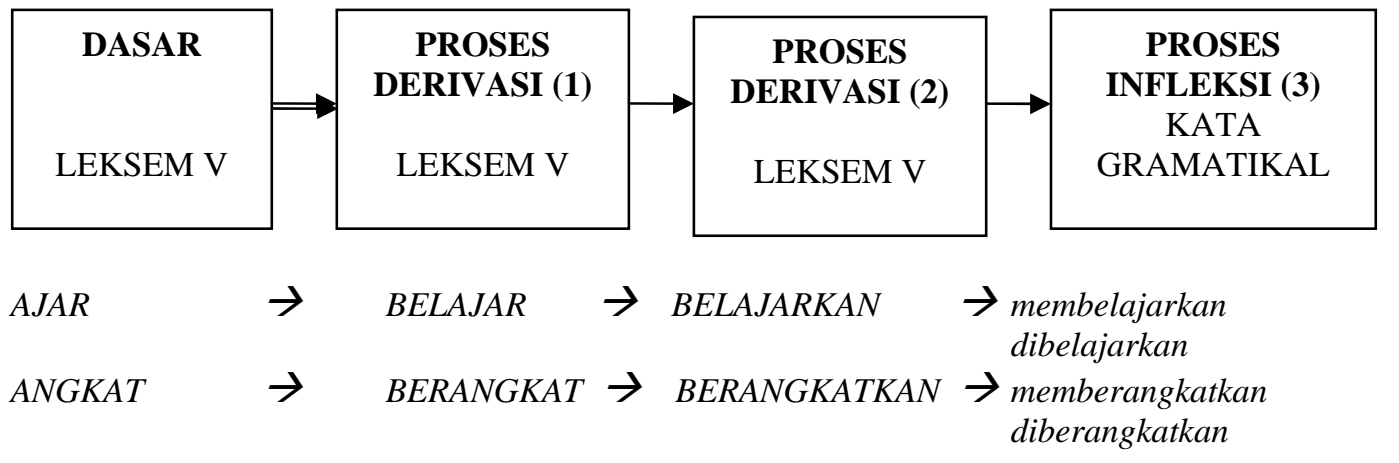


POLA (III): D + PROSES DERIVASI (1) + PROSES DERIVASI (2)

+ PROSES INFLEKSI (3).

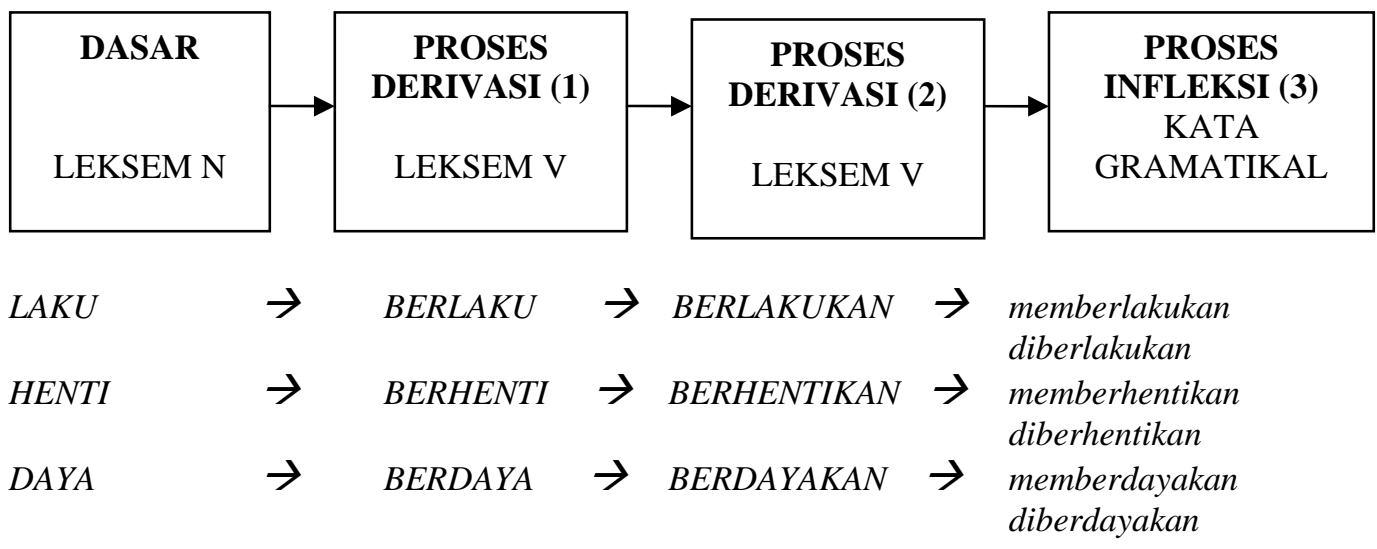

Pada contoh verba di atas, terlihat adanya tiga hierarki afiksasi. Hierarki yang pertama adalah pengimbuhan afiks derivasi beR- pada DV AKSI PROSES (derivasi taktransposisional) dan DN (derivasi transposisional) dan hierarki yang kedua adalah pengimbuhan afiks derivasi -kan pada DV AKSI dengan proses derivasi taktransposisional, serta hierarki yang ketiga adalah pengimbuhan afiks infleksi meN- dan di- dengan proses infleksi.

Pengimbuhan afiks derivasi (Proses Derivasi 1) menurunkan leksem V AKSI (V Taktransitif) seperti BELAJAR, BERANGKAT, BERLAKU, BERHENTI, BERDAYA dari DV AKSI PROSES seperti AJAR, ANGKAT atau DN seperti LAKU, HENTI, DAYA. Selanjutnya, pengimbuhan afiks derivasi (Proses Derivasi 2) menurunkan leksem V AKSI PROSES (V Transitif) seperti BELAJARKAN, BERANGKATKAN, BERLAKUKAN, BERHENTIKAN, BERDAYAKAN, serta pengimbuhan afiks infleksi (Proses Infleksi 3) membentuk kata gramatikal berkategori AKTIF seperti membelajarkan, memberangkatkan, memberlakukan, 
memberhentikan, memberdayakan dan kata gramatikal berkategori PASIF seperti dibelajarkan, diberangkatkan, diberlakukan, diberhentikan, diberdayakan.

\subsection{Hierarki Afiksasi pada V KEADAAN, V PROSES, V AKSI (V INTRAN- SITIF)}

Hierarki afiksasi pada $\mathrm{V}$ KEADAAN, $\mathrm{V}$ PROSES, V AKSI (V INTRANSITIF) ditemukan dalam dua pola berikut ini. Pertama, hierarki afiksasi dengan pola (IV) yakni D + PROSES DERIVASI. Hierarki afiksasi ini terdapat pada V KEADAAN, V PROSES, V AKSI (V INTRANSITIF) yang diturunkan dari DN, DA, DV KEADAAN, DV PROSES, DV AKSI dengan pengimbuhan afiks derivasi meN-, beR-, teR-, ke-/-an, beR-/-an, beR-/-kan. Kedua, hierarki afiksasi dengan pola (V) D + PROSES INFLEKSI (afiks infleksi ber-). Pola hierarki afiksasi ini terdapat pada V AKSI atau V KEADAAN yang berfitur semantis aksi mental dengan pengimbuhan afiks infleksi beR-.

Dalam BI, V KEADAAN, V PROSES, V AKSI (V INTRANSITIF) dapat diturunkan dengan proses derivasi (1) dari DN dan DA. Hierarki afiksasinya sesuai dengan POLA (IV): D + PROSES DERIVASI (1) seperti berikut ini.

POLA (IV): D + PROSES DERIVASI (1)

\begin{tabular}{|c|c|c|}
\hline $\begin{array}{c}\text { DASAR } \\
\text { LEKSEM N/ } \\
\text { LEKSEM A }\end{array}$ & $\longrightarrow$ & $\begin{array}{c}\text { PROSES DERIVASI (1) } \\
\text { LEKSEM V }\end{array}$ \\
\hline RUMPUT & $\rightarrow$ & MERUMPUT \\
\hline DARAT & $\rightarrow$ & MENDARAT \\
\hline JAMUR & $\rightarrow$ & MENJAMUR \\
\hline BATU & $\rightarrow$ & MEMBATU \\
\hline GUNA & $\rightarrow$ & BERGUNA \\
\hline
\end{tabular}




$\begin{array}{lll}\text { NYAWA } & \rightarrow & \text { BERGUNA } \\ \text { BUNGA } & \rightarrow & \text { BERBUNGA } \\ \text { DAUN } & \rightarrow & \text { BERDAUN } \\ \text { KOMUNIKASI } & \rightarrow & \text { BERKOMUNIKASI } \\ \text { KURANG } & \rightarrow & \text { BERKURANG } \\ \text { POJOK } & \rightarrow & \text { TERPOJOK } \\ \text { TULANG } & \rightarrow & \text { TERTULANG } \\ \text { RACUN } & \rightarrow & \text { KERACUNAN } \\ \text { HUJAN } & \rightarrow & \text { KEHUJANAN } \\ \text { DINGIN } & \rightarrow & \text { KEDINGINAN } \\ \text { PANAS } & \rightarrow & \text { KEPANASAN } \\ \text { SAMPING } & \rightarrow & \text { BERSAMPINGAN } \\ \text { HADAP } & \rightarrow & \text { BERHADAPAN } \\ \text { MESRA } & \rightarrow & \text { BERMESRAAN } \\ \text { SUAMI } & \rightarrow & \text { BERSUAMIKAN } \\ \text { ISTRI } & \rightarrow & \text { BERISTRIKAN } \\ \text { SENJATA } & \rightarrow & \text { BERSENJATAKAN } \\ \text { SUNTING } & \rightarrow & \text { BERSUNTINGKAN }\end{array}$

Pada contoh verba di atas, terlihat adanya satu kali hierarki pengimbuhan afiks yakni pengimbuhan afiks derivasi $m e N-$, beR-, teR-, ke-/-an, beR-/-an, beR-/kan pada DN dan DA (derivasi transposisional). Proses derivasi ini menurunkan leksem V KEADAAN, V PROSES, V AKSI (V Taktransitif) dari DN dan DA.

Selain itu, V KEADAAN, V PROSES, V AKSI (V INTRANSITIF) dapat pula diturunkan dengan proses derivasi taktransposisional dari DV. Pola hierarki afiksasinya adalah POLA (IV): D + PROSES DERIVASI (1) seperti berikut ini.

POLA (IV): D + PROSES DERIVASI (1)

\begin{tabular}{|c|c|c|}
\hline DASAR & & PROSES DERIVASI (1) \\
\hline LEKSEM V & & LEKSEM V \\
\hline TETAP & $\rightarrow$ & MENETAP \\
\hline HILANG & $\rightarrow$ & MENGHILANG \\
\hline ANGKAT & $\rightarrow$ & BERANGKAT \\
\hline$A J A R$ & $\rightarrow$ & BELAJAR \\
\hline JEMUR & $\rightarrow$ & BERJEMUR \\
\hline
\end{tabular}




$\begin{array}{lll}\text { JAHIT } & \rightarrow & \text { BERJAHIT } \\ \text { TERIMA } & \rightarrow & \text { BERTERIMA } \\ \text { PUTUS } & \rightarrow & \text { TERPUTUS } \\ \text { DUDUK } & \rightarrow & \text { TERDUDUK } \\ \text { HAMBAT } & \rightarrow & \text { TERHAMBAT } \\ \text { BINGUNG } & \rightarrow & \text { KEBINGUNGAN } \\ \text { LAPAR } & \rightarrow & \text { KELAPARAN } \\ \text { HABIS } & \rightarrow & \text { KEHABISAN } \\ \text { TUMPAH } & \rightarrow & \text { KETUMPAHAN } \\ \text { MASUK } & \rightarrow & \text { KEMASUKAN } \\ \text { TERBANG } & \rightarrow & \text { BETERBANGAN } \\ \text { MUNCUL } & \rightarrow & \text { BERMUNCULAN } \\ \text { DATANG } & \rightarrow & \text { BERDATANGAN } \\ \text { PELUK } & \rightarrow & \text { BERPELUKAN } \\ \text { SAHUT } & \rightarrow & \text { BERSAHUTAN } \\ \text { MANDI } & \rightarrow & \text { BERMANDIKAN } \\ \text { TABUR } & \rightarrow & \text { BERTABURKAN } \\ \text { HIAS } & \rightarrow & \text { BERHIASKAN }\end{array}$

Pada contoh verba di atas, terlihat adanya satu kali hierarki pengimbuhan afiks derivasi meN-, beR-, teR-, ke-/-an, beR-/-an, beR-/-kan pada DV (derivasi taktransposisional). Pengimbuhan afiks derivasi ini menurunkan leksem $\mathrm{V}$ KEADAAN, V PROSES, V AKSI (V Taktransitif) dari DV.

Hierarki afiksasi dengan POLA (V) terdapat pada V AKSI tertentu atau V KEADAAN yang memiliki fitur semantis aksi mental yang dibentuk dengan afiks infleksi beR- seperti bekerja, berkonsultasi, berlari, berbicara, berunjuk rasa, bergembira, bersedih, berbahagia, bersabar, berada, dll. Hierarki afiksasi pada verba itu adalah POLA (V): D + PROSES INFLEKSI (1) dengan afiks infleksi beRseperti berikut ini.

POLA (V): D + PROSES DERIVASI (1) dengan Afiks Infleksi beR-

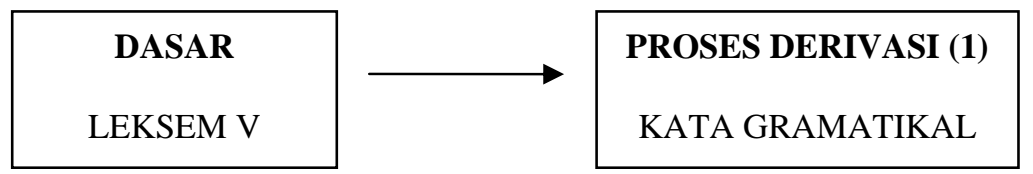

Vol. 14, No. 26, Maret 2007

SK Akreditasi Nomor: 39/Dikti/Kep. 2004 


$\begin{array}{lll}\text { KERJA } & \rightarrow & \text { bekerja } \\ \text { KONSULTASI } & \rightarrow & \text { berkonsultasi } \\ \text { LARI } & \rightarrow & \text { berlari } \\ \text { BICARA } & \rightarrow & \text { berbicara } \\ \text { UNJUR RASA } & \rightarrow & \text { berunjuk rasa } \\ \text { GEMBIRA } & \rightarrow & \text { bergembira } \\ \text { SEDIH } & \rightarrow & \text { bersedih } \\ \text { BAHAGIA } & \rightarrow & \text { berbahagia } \\ \text { SABAR } & \rightarrow & \text { bersabar } \\ \text { ADA } & \rightarrow & \text { berada }\end{array}$

Pada contoh verba di atas, terlihat adanya satu kali hierarki pengimbuhan afiks infleksi beR- pada DV atau DV KEADAAN dengan proses infleksi. Pengimbuhan afiks infleksi (Proses Infleksi) tersebut membentuk kata gramatikal dengan kategori RAGAM FORMAL. Afiks infleksi kategori RAGAM FORMAL ini dilihat berdasarkan pragmatik (kontekstual). Kiefer (2001:274) mengemukakan dalam bahasa Hungaria, pemilihan sufiks infleksi mempunyai konsekuensi stilistik. Makna stilistik sufiks berada dalam rentangan ragam tidak formal ke ragam formal. Selain itu, Boiij (2005:109) juga mengemukakan dalam bahasa Jerman, adjektif atributif mempunyai dua pola infleksi kontekstual yang secara tradisional disebut: (1) infleksi lemah (weak inflection) yakni telah memiliki “definite article) dan infleksi kuat (strong inflection) yakni yang simpel/sederhana. Infleksi lemah adalah bentuk yang kurang formal (tidak formal) sedangkan infleksi kuat adalah bentuk yang formal secara kontekstual. 


\section{Simpulan dan Saran}

\subsection{Simpulan}

Berdasarkan uraian di atas, dapat disimpulkan bahwa pada verba afiksasi BI terdapat lima pola hierarki afiksasi. Pertama, pola (I) adalah D + PROSES INFLEKSI. Pola hierarki afiksasi ini terjadi jika verba AKSI PROSES (V Transitif) hanya memiliki satu afiks infleksi meN- atau afiks infleksi di-. Kedua, pola (II) adalah (D + PROSES DERIVASI) + PROSES INFLEKSI. Pola hierarki afiksasi ini terjadi jika verba AKSI PROSES (V Transitif) selain memiliki afiks infleksi meNatau afiks infleksi di- juga memiliki afiks derivasi lain, seperti -kan, -i, per-/-kan, per-/-i, per-. Ketiga, pola (III) adalah ((D + PROSES DERIVASI) + PROSES DERIVASI) + PROSES INFLEKSI. Pola hierarki afiksasi ini terjadi jika verba AKSI PROSES (V Transitif) selain memiliki afiks infleksi meN- atau afiks infleksi di- juga memiliki afiks derivasi lain seperti afiks ber-, dan -kan. Keempat, pola (IV) adalah D + PROSES DERIVASI. Hierarki afiksasi ini terdapat pada V KEADAAN, V PROSES, V AKSI (V INTRANSITIF) yang diturunkan dari DN, DA, DV KEADAAN, DV PROSES, DV AKSI dengan pengimbuhan afiks derivasi meN-, beR-, teR-, ke-/-an, beR-/-an, beR-/-kan. Kelima, pola (V) adalah D + PROSES INFLEKSI (afiks infleksi ber-). Pola hierarki afiksasi ini terdapat pada V AKSI atau V KEADAAN yang berfitur semantis aksi mental dengan pengimbuhan afiks infleksi beR-. 


\subsection{Saran}

Kepada peneliti lainnya, disarankan untuk mengkaji sistem morfologi bahasa Indonesia dari perspektif derivasi dan infleksi. Selain kajian hierarki afiksasi pada kata turunan, juga perlu dikaji proses afiksasi, reduplikasi dari tinjauan morfologi derivasi dan infleksi ini.

\section{KEPUSTAKAAN}

Alieva, N.F dkk. 1991. Bahasa Indonesia: Deskripsi dan Teori. Yogyakarta: Kanisius.

Alwi, Hasan dkk. 1998. Tata Bahasa Baku Bahasa Indonesia (Edisi Ketiga). Jakarta: Balai Pustaka.

Aronoff, Mark and Fudeman, Kirsten. 2005. What is Morphology? Malden:Blackwell Publishing

Bauer, Laurie. 1988. Introducing Linguistic Morphology. Edinburgh: Edinburgh University Press.

Bauer, Laurie. 1983. English Word Formation. Cambridge: Cambridge University Press.

Beard, Robert. 2001. "Derivation” dalam Andrew Spencer and Anold M. Zwicky (eds) The Handbook of Morfology. Malden: Blackwell Publishers

Bloomfield, Leonard. 1995. Bahasa. Jakarta: Gramedia.

Boiij, Geert. 2005. The Grammar of Words: An Introduction to Linguistic Morphology. New York: Oxford University Press.

Chaer, Abdul. 2003. Seputar Tata Bahasa Baku Bahasa Indonesia. Jakarta: Rineka Cipta.

Chafe, Wallace L. 1970. Meaning and The Structure of Language. Chicago: The University of Chicago Press.

Dik, S.C \& Kooij, J.G. 1994. Ilmu Bahasa Umum. Jakarta: Pusat Pembinaan dan Pengembangan Bahasa RI dan Universitas Leiden

Fillmore, Charles J. 1971. "Some Problems for Case Grammar". Georgetown University Round Table on Languages and Lingusitics. Washington:Georgetown University Press.

Hatch, Evelyn and Brown, Cheryl. 1995. Vocabulary, Semantics, and Language Education. Cambridge: Cambridge University Press.

Kiefer, Ferenz. 2001. "Morphology and Pragmatics" dalam Andrew Spencer and Anold M. Zwicky (eds) The Handbook of Morphology. Malden: Blackwell Publishers 
Kridalaksana, Harimurti.1996. Pembentukan Kata dalam Bahasa Indonesia. Jakarta: Gramedia Pustaka Utama.

Lyons, John. 1968. Introduction to Theoretical Linguistics. Cambridge: Cambridge University Press.

Matthews, P.H. 1974. Morphology: An Introduction to The Theory of WordStructure. Cambridge: Cambridge University Press.

Mahsun. 2005. Metode Penelitian Bahasa. Jakarta: Raja Grafindo Persada.

Nida, Eugene A. 1949. Morphology: The Descriptive Analysis of Words (Second Edition). Ann Arbor: The University of Michigan Press.

Poedjosoedarmo, Soepomo dkk. 1979. Morfologi Bahasa Jawa. Jakarta: Pusat Pembinaan dan Pengembangan Bahasa.

Radford, Andrew dkk. 1999. Linguistic: An Introduction. Cambridge: Cambridge Unoiversity Press.

Ramlan, M. 1987. Ilmu Bahasa Indonesia, Morfologi: Suatu Tinjauan Deskriptif. Yogyakarta: CV Karyono

Robins, R.H. 1992. Lingusitik Umum: Sebuah Pengantar. Yogyakarta: Kanisius.

Samsuri. 1987. Analisis Bahasa: Memahami Bahasa secara Alamiah. Jakarta: Erlangga.

Scalise, Sergio. 1984. Generative Morphology. Dordrecht-Holland:Foris Publication.

Stump, Gregory. 2001. "Inflection” dalam Andrew Spencer and Anold M. Zwicky (eds) The Handbook of Morfology. Malden: Blackwell Publishers

Subroto, D. Edi. 1992. Pengantar Metode Penelitian Struktural. Surakarta: Sebelas Maret University Press.

Sudaryanto. 1993. Metode dan Aneka Teknik Analisis Bahasa: Pengantar Penelitian Wahana Kebudayaan secara Linguistis. Yogyakarta: Duta Wacana University Press.

Sudaryanto. 1989. "Perkembangan Tipologi Bahasa: Tinjauan Selayang” dalam Bambang Kaswanti Purwo (penyunting), PELLBA 2. Yogyakarta: Penerbit Kanisius.

Tim Penyusun Kamus Pusat Bahasa. 2005. Kamus Besar Bahasa Indonesia. Jakarta: Balai Pustaka

Widdowson, H.G. 1997. Linguistics. New York: Oxford University Press.

Yule, George. 1996. The Study of Language (Second edition). Cambridge: Cambridge University Press. 
Vol. 14, No. 26, Maret 2007

SK Akreditasi Nomor: 39/Dikti/Kep. 2004 